\title{
Isotopic and mineralogical variations in the infill of Chondrites from organic- rich black shale (Posidonia Shale, Germany) for assessing the mode of colonization
}

\section{Kentaro IZUMI*}

Department of Earth and Planetary Science, University of Tokyo, 7-3-1 Hongo, Bunkyo-ku, Tokyo 113-0033, Japan; izumi@eps.s.u-tokyo.ac.jp

* Corresponding author

Izumi, K. 2014. Isotopic and mineralogical variations in the infill of Chondrites from organic-rich black shale (Posidonia Shale, Germany) for assessing the mode of colonization [Variaciones isotópicas y mineralógicas en el relleno de Chondrites procedentes de pizarras negras ricas en materia orgánica para evaluar el modo de colonización]. Spanish Journal of Palaeontology, 29 (2), 107-116.

\begin{abstract}
The compositional variations of the infill of Chondrites within the Toarcian (Lower Jurassic) organic-rich black shale of southern Germany were evaluated on the basis of organic carbon-isotope and XRD analyses of the infill, surrounding black shale, and overlying greenish-grey mudstone for assessing the mode of colonization by the trace-maker. Both carbon-isotope ratios and the mineralogical compositions (i.e., quartz/calcite peak-height-ratio) of the infill show much larger variations than those of the overlying mudstone and ambient black shale. These lines of evidence strongly confirm the prolonged upward migration model, and the short-term opportunistic colonization model is not likely in this case. Although the obtained data cannot directly provide any evidence of the chemosymbiotic trace-maker model, this study also indicates that the isotopic and mineralogical variations recorded in the infill of Chondrites can be used as good indicators to assess the trace-maker's colonization style, furthermore to distinguish opportunistic/climax trace fossil.
\end{abstract}

Keywords: Trace fossils, organic carbon-isotope, mineralogy, colonization, black shale.

\section{RESUMEN}

Se ha estudiado las variaciones en la composición del relleno de Chondrites procedentes de las pizarras negras toarcienses -ricas en materia orgánica- del Jurásico Inferior del sur de Alemania. El estudio ha comprendido análisis de isótopos de carbono orgánico y difracción de rayos X, tanto del relleno de las madrigueras como de la pizarra negra encajante y de la lutita gris verdosa suprayacente, con objeto de evaluar el modo de colonización del organismo productor. Las relaciones isotópicas de carbono y las composiciones mineralógicas (relación de alturas de pico de cuarzo/calcita) medidas para el relleno muestran variaciones mucho mayores que para la lutita suprayacente y la pizarra negra que rodea a las madrigueras. Estas líneas de evidencia apoyan con fuerza el modelo de migración hacia arriba prolongada, haciendo poco verosímil en este caso el modelo de colonización oportunista de corto plazo. Si bien los datos obtenidos no proporcionan una evidencia directa del modelo del productor quimiosimbiótico, el presente estudio concluye que las variaciones isotópicas y mineralógicas registradas en el relleno de Chondrites pueden utilizarse como buenos indicadores para estimar el estilo de colonización del organismo productor, además de para distinguir entre pistas fósiles de tipo oportunista y de clímax.

Palabras clave: Pistas fósiles, isótopos de carbono orgánico, mineralogía, colonización, pizarras negras. 


\section{INTRODUCTION}

Trace fossils are interpreted as useful tools in various disciplines such as palaeontology, sedimentology and palaeoceanography because they provide not only meaningful information about the palaeoenvironments in which the trace-producing animals lived but also significant information about the palaeoecology of these animals (e.g., Seilacher, 1967a, b, 2007; Buatois \& Mángano, 2011; Knaust \& Bromley, 2012; Mángano \& Buatois, 2012).

The ichnogenus Chondrites exhibits a regularly branching burrow system, and is a distinctive and common trace fossil appearing in fine-grained sedimentary rocks in a wide range of depositional settings (e.g., Gerard \& Bromley, 2008). In addition, Chondrites is one of the most intriguing and significant trace fossils because it has been regarded as an indicator of low-oxygen conditions in sediments (e.g., Bromley \& Ekdale, 1984; Savrda \& Bottjer, 1986; Ekdale \& Mason, 1988).

Despite the common occurrence and the significant palaeoenvironmental aspect of this ichnogenus, the palaeoecology of the Chondrites-producing animal, especially mode of colonization, is still somewhat controversial. Traditionally, particularly when Chondrites shows a monospecific and highly dense occurrence within such sediments as organic-rich black shale, its trace- maker has been considered as an opportunistic depositfeeding animal and has been interpreted to have shown a short-term colonization under oxygen-depleted conditions (e.g., Seilacher \& Westphal, 1983; Ekdale, 1985; Fig. 1a). However, because of many mechanical and ethological problems associated with the deposit-feeding model, Chondrites has recently been reinterpreted as "sulphidewell" constructed by the activity of a chemosymbiotic worm-like organism that was specially adapted to sulphiderich sediments (e.g., Seilacher, 1990, 2007; Fu, 1991). According to the chemosymbiosis model, Chondrites can be regarded as a climax form that has a highly narrow trophic character rather than an opportunistic ichnogenus (i.e., sulphide-rich environments) (e.g., Fu \& Werner, 1994; Bromley, 1996). In that case, dense occurrence of Chondrites within black shale suggests a prolonged upward migration model as proposed by Savrda \& Bottjer (1989) (Fig. 1b), not a short-term colonization. In addition, the fact that Chondrites occasionally shows an exaggerated association with sites of organic richness (e.g., black shale) seems to be consistent with the chemosymbiosis model (Bromley, 1996).

In order to resolve these controversial arguments about the colonization style of the Chondrites-producer, it is important to correctly evaluate the compositional variations of the infill of Chondrites within organic-rich

(a) RAPID SHORT-TERM COLONIZATION MODEL (OPPORTUNISTIC)

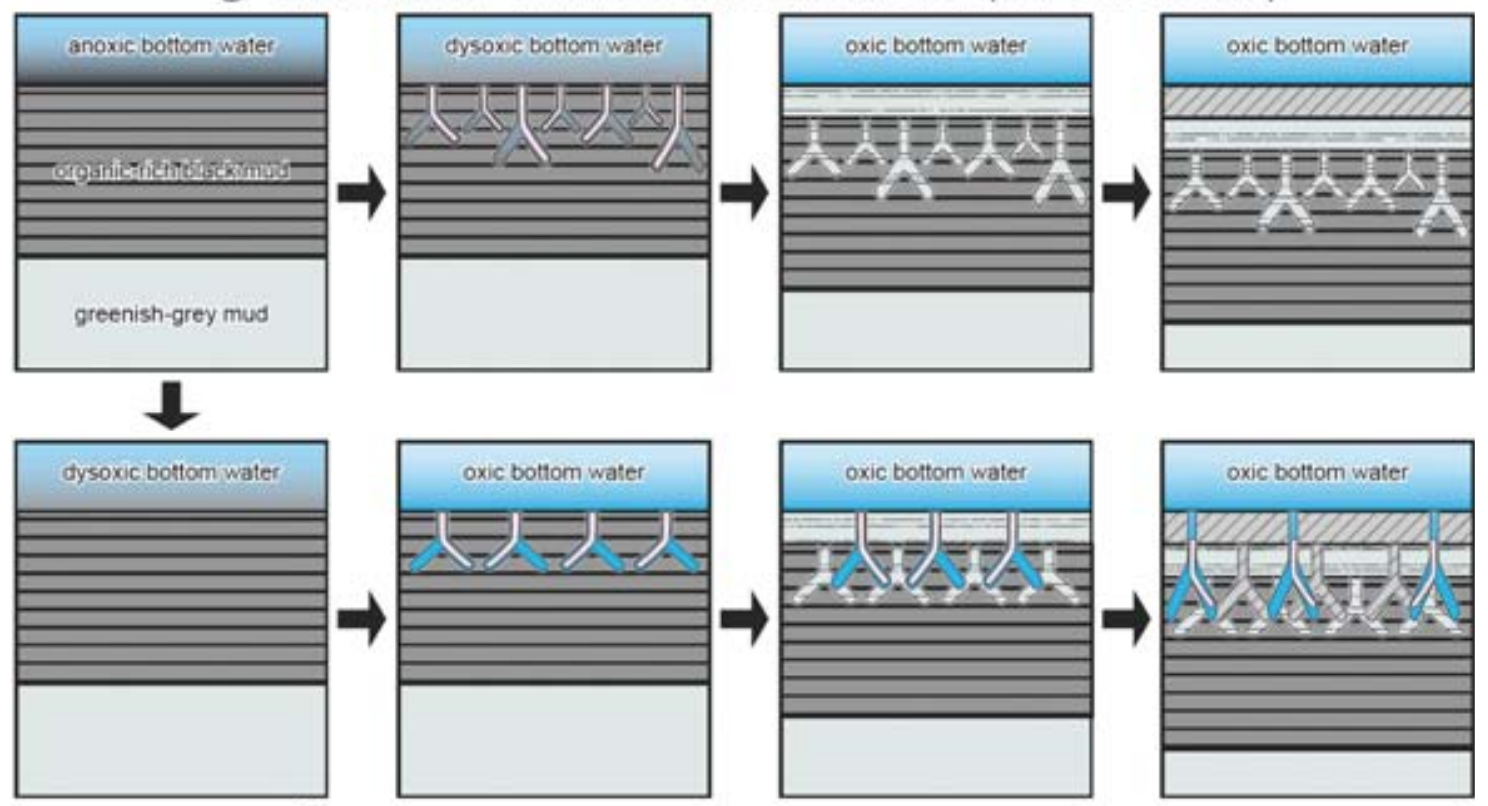

(b) PROLONGED UPWARD MIGRATION MODEL (CLIMAX)

Figure 1. Schematic diagrams illustrating the colonization styles by the trace-makers of Chondrites within the organic-rich black shale. Not to scale. a) Short-term colonization model based on Seilacher \& Westphal (1983) and Ekdale (1985). This model assumes that the trace-maker was an opportunistic animal. The infill must have highly uniform compositions. b) Prolonged upward migration model based on Savrda \& Bottjer (1989). In that case, Chondrites can be interpreted as a climax form. The infill must show a significant compositional variation. 
sediments. The infill of Chondrites has generally been interpreted to have been passively introduced from the overlying sediments (e.g., Richer, 1927, 1931; Simpson, 1957; Ferguson, 1965; Osgood, 1970; Seilacher, 1977a, b). Although experiments using a glass model of a portion of a Chondrites network demonstrated that fine-grained clay particles could fill up to $87 \%$ of the entire system (Osgood, 1970), he also stated that it might be even easier to fill the burrow under the actual geological processes given the actual sediment inflow into the burrow. Kotake (1991) claimed that the Chondrites infill was actively packed by the deposit-feeding activity of the producer, however his specimens have recently been reinterpreted as Phymatoderma (Izumi, 2013). Therefore, if the Chondrites-producer showed the short-term colonization, the composition of the infill must be highly homogeneous (Fig. 1a), whereas the infill must have considerable compositional variations if the trace-maker showed the prolonged upward migration (Fig. 1b).

Thus, the present work shows the isotope-geochemical/ mineralogical study to assess the compositional variations of the infill of Chondrites and to shed further light on the trace-maker's colonization style from a new perspective. Chemical and mineralogical analyses of Chondrites themselves have been carried out long time ago (e.g., Krasser, 1889; Pfaft, 1901; Tauber, 1949), but this paper is the first study to pay attention to compositional variations. Samples were collected from the Toarcian (Lower Jurassic) organic-rich black shale exposed in the Dotternhausen area of southern Germany. The variations of the Chondrites infill were determined on the basis of comparisons between the carbon-isotope ratios and mineralogical compositions of the infill, surrounding black shale, and overlying sediment.

\section{GEOLOGICAL SETTING}

The Toarcian (Lower Jurassic) organic-rich black shale facies, commonly known as "Posidonienschiefer" or "Posidonia Shale" (e.g., Riegraf et al., 1984; Röhl et al., 2001), is well exposed at numerous quarries along a northeast-trending belt in southern Germany (Fig. 2a).

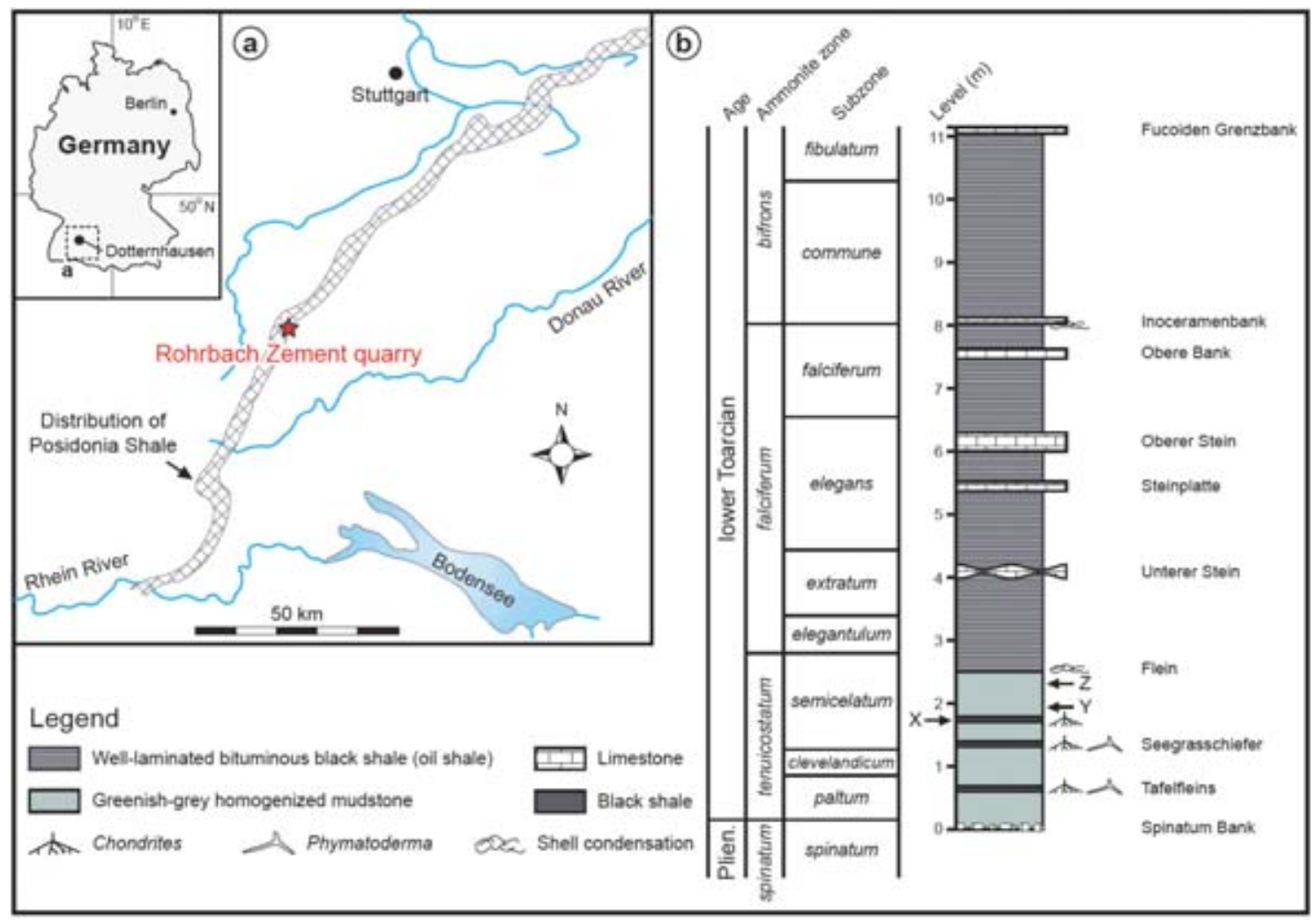

Figure 2. Geological setting and stratigraphy of the Dotternhausen section. a) Distribution of the Posidonia Shale across southern Germany, and the locality of the studied section, Rohrbach Zement quarry. Modified after Savrda \& Bottjer (1989). b) Litho- and bio-stratigraphy for the uppermost Pliensbachian to the lower Toarcian sequence at the study section. After Riegraf et al. (1984) for ammonite biostratigraphy. Chondrites-bearing black shale and the overlying greenish-grey mudstone for isotopic analysis were collected from the horizon X and Y, respectively. Modified after Izumi (2012). Carbon-isotope ratio of the greenish-grey mudstone from horizon $\mathrm{Z}$ analysed by Röhl et al. (2001) is used as reference data. 
The black shale was deposited under oxygen-depleted conditions within the European epicontinental shallow basins (e.g., Kauffman, 1981; Ziegler, 1982, 1988; Bassoulet et al., 1993; Röhl \& Schmid-Röhl, 2005). In this study, detailed fieldwork and sampling of the Chondritesbearing rocks were also carried out at an outcrop exposed at the Rohrbach Zement quarry (Figs 2b, 3a), which has been well investigated in terms of stratigraphy, palaeontology, sedimentology, and geochemistry (e.g., Riegraf et al., 1984; Röhl et al., 2001; Schmid-Röhl \& Röhl, 2003; Frimmel et al., 2004; Schwark \& Frimmel, 2004).

The study section is $11.2 \mathrm{~m}$ thick and is correlated to the uppermost Pliensbachian to the lower Toarcian by previous biostratigraphical studies (e.g., Riegraf et al., 1984). At the base of the section, limestone concretions ("Spinatum Bank") occur in the greenish-grey homogenized mudstones (Fig. 2b). This facies persisted until the upper part of the Dactylioceras tenuicostatum Zone, except for three black shale layers, two of which were previously recognized as "Tafelfleins" and "Seegrasschiefer" beds (Fig. 2b). These layers are characterized by the dense occurrence of trace fossils such as Chondrites and Phymatoderma (Fig. 3b). The greenish-grey mudstones are overlain by well-laminated organic-rich black shales (oil shales) that range from the upper part of the $D$. tenuicostatum Zone to the Hildoceras bifrons Zone (Fig. 2b). Limestone beds are intercalated in the oil shales at seven horizons (Fig. 2b). The oil shales rarely contain fossils of apparent benthic organisms except for two bivalve-condensed horizons ("Flein" and the base of "Inoceramenbank"; Fig. 2b).

The studied trace-fossil specimens were collected from the black-shale horizon labeled as $\mathrm{X}$ within the middle part of the D. tenuicostatum Zone (Fig. 2b).

\section{MATERIALS AND METHODS}

\subsection{Chondrites from the Dotternhausen section and its description}

In the study section, Chondrites was recognized from the three black shale horizons in the D. tenuicostatum Zone (Fig. 2b), and typically shows a dense occurrence (Fig. 3b). The occurrence of Chondrites is commonly concentrated in the upper part of these black shale beds, and the penetration depth into the black shale is approximately $5 \mathrm{~cm}$.

Diameter of regularly brunched tunnels is constant in the same burrow system (Fig. 4a) but varies from 0.5 to $5 \mathrm{~mm}$ among different specimens. Chondrites from horizon X (Fig. 2b) is larger (generally 1 to $3 \mathrm{~mm}$ in diameter; Figs 4a-c) than that from the "Tafelfleins" and "Seegrasschiefer" beds, which is generally 0.5 to $2 \mathrm{~mm}$ in diameter (Fig. 3b). The tunnel has no lining. The infill appears to be homogenized with no remarkable structures such as pellets observed in each tunnel (Figs 4c-d). The infill is obviously different in colour from the surrounding black shale (Fig. 4) and resembles the overlying mudstone. Almost completely pyritized infill is occasionally observed (Fig. 4b).

\subsection{Organic carbon-isotope analysis}

In order to evaluate the isotopic variation in the infill of Chondrites from the Dotternhausen section, carbon-isotope values of organic carbon $\left(\delta^{13} \mathrm{C}_{\text {org }}\right)$ of the infill, surrounding black shale, and overlying mudstone were analysed.
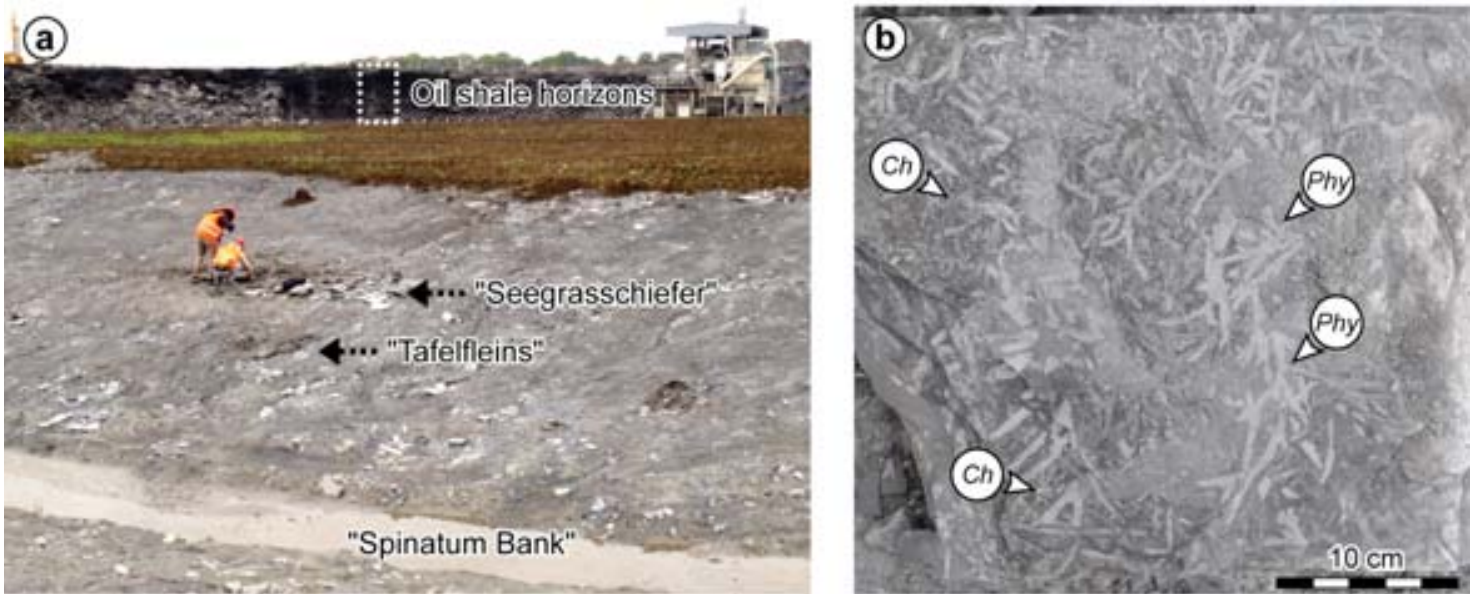

Figure 3. Field photographs of the study section and observed trace fossils. a) Photograph of the Rohrbach Zement quarry, illustrating the horizons of some characteristic beds. Geologists (ca. $170 \mathrm{~cm}$ ) for scale. b) Example of the extremely dense occurrence of trace fossils in a black-shale horizon ("Seegrasschiefer" bed). View parallel to the bedding plane. Phy: Phymatoderma granulata; Ch: Chondrites isp. Note that $P$. granulatea has a larger diameter than Chondrites isp. 

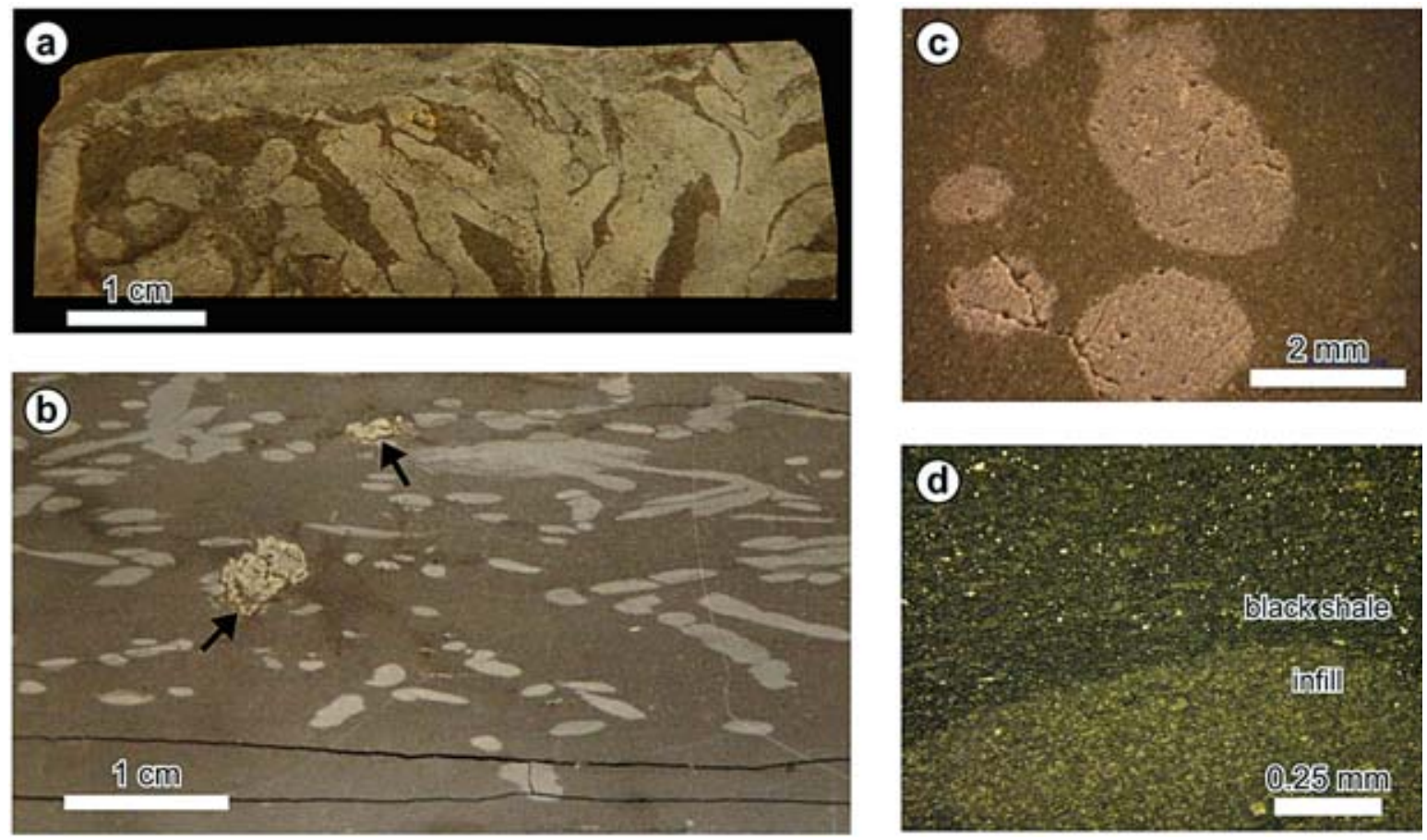

Figure 4. Photographs of Chondrites from the Toarcian Posidonia Shale at the Dotternhausen section (Horizon $\mathrm{X})$. a) Chondrites showing regularly branching tunnels with the approximately constant diameter. View parallel to the bedding plane. b) Example of Chondrites showing the dense occurrence. Pyritized infill (black arrow) can be occasionally recognized. Vertical cross section. c) Photomicrograph of the infill of Chondrites. Note that structures such as faecal pellets cannot be visible. View parallel to the bedding plane. d) Photomicrograph of the infill/black-shale boundary. The infill is homogenized, and faecal pellets cannot be observed. Vertical cross section.

Chondrites and the ambient black shale from horizon $\mathrm{X}$ (Fig. 2b) and the overlying mudstone from horizon Y (Fig. 2b) were used for carbon-isotope analysis.

For carbon-isotope analysis preparations, the infill of Chondrites, surrounding black shale, and overlying greenish-grey mudstone were powdered using a microdrill, and the powders were then treated with $20 \%$ hydrochloric acid to remove all carbonates and other acid-soluble minerals. Each powder sample was sealed in a Sn foil for isotope analysis (approximately 1-2 $\mathrm{mg}$ for infill, 0.3-0.5 mg for black shale, and 2-3 mg for mudstone). Bulk carbon-isotope values of organic carbon were measured using a Finnigan MAT 253 isotope ratio mass spectrometer attached to an elemental analyzer (FLASH 2000, ThermoFinnigan) through an interface system (Conflo4, ThermoFinnigan) at the Department of Geology and Palaeontology, National Museum of Nature and Science, Tokyo. The measurements for each sample were carried out three times and the mean value of the results was used as the $\delta^{13} \mathrm{C}_{\text {org }}$ ratio of the sample. The precision of the measurements was approximately $\pm 0.15 \%$ o (1 SD). Isotopic ratios are reported relative to the Vienna Pee Dee Belemnite (VPDB) standard.

\subsection{Mineralogical analysis}

For evaluating the mineralogical variation in the infill of Chondrites, bulk-fraction X-ray diffraction (XRD) analysis was carried out for the infill, surrounding black shale, and overlying mudstone. Sample horizons are exactly the same as those for the carbon-isotope analysis.

For XRD analysis, powdered samples (two powder samples for each lithofacies) were prepared in the same procedure in the carbon-isotope analysis. These bulk powdered samples were analysed with X'PertPro diffractometer (Panalytical), at the Department of Earth and Planetary Science, University of Tokyo, using monochromatic $\mathrm{Cu} \mathrm{Ka}$ radiation operated at $45 \mathrm{kV}$ and $40 \mathrm{~mA}$. The detector used was a scintillation counter. To obtain the general XRD traces ( 5 to $55^{\circ} 2 \Theta$ ), samples were scanned with a step size of $0.017^{\circ}$ and a count time of 30.5 seconds per step. For obtaining more accurate traces especially of low-angled area $\left(7\right.$ to $\left.14^{\circ} 2 \theta\right)$, selected powder samples were then scanned with the same step size and a count time of 360 seconds per step. 


\section{RESULTS}

\subsection{Organic carbon-isotope ratios}

The carbon-isotope values for the infill of Chondrites, surrounding black shale, and overlying greenish-grey mudstone are summarized in Table 1 and Figure 5. Carbonisotope ratios of the infill of Chondrites, surrounding black shale, and overlying greenish gray mudstone vary between -27.3 and $-26.9 \%$ o $(\mathrm{n}=5),-28.4$ and $-28.3 \%$ o $(\mathrm{n}=8)$, and -26.7 and $-26.5 \%$ ( $(\mathrm{n}=3)$, respectively. The $\delta^{13} \mathrm{C}_{\text {org }}$ value of the Chondrites infill is similar to that of the overlying mudstone, but significantly differs from that of the surrounding black shale (Fig. 5). As for the overlying greenish-grey mudstone, the number of samples analysed is small because the mudstone from horizon $\mathrm{Y}$ is nearly completely homogenized. Despite the small number of samples, sample standard deviation of the $\delta^{13} \mathrm{C}_{\text {org }}$ value of overlying mudstone is quite small $(0.08 \%$; Table 1$)$. On the other hand, sample standard deviation of the $\delta^{13} \mathrm{C}_{\text {org }}$ ratio of the infill is highly large $(0.20 \%)$ compared with that of the other two lithofacies (Table 1).

Table 1. Results of carbon-isotope analysis of organic carbon. $\mathrm{SD}$ : sample standard deviation; $\mathrm{n}$ : the number of measured samples.

\begin{tabular}{|c|c|c|c|c|}
\hline \multirow{2}{*}{ Lithofacies } & \multirow{2}{*}{ Horizon } & \multicolumn{2}{|c|}{$\delta^{13} \mathrm{C}_{\mathrm{org}}(\%)$} & \multirow{2}{*}{$\mathrm{n}$} \\
\hline & & Mean & SD & \\
\hline Infill of Chondrites & $X$ & -27.1 & 0.20 & 5 \\
\hline Black shale & $\mathrm{X}$ & -28.3 & 0.05 & 8 \\
\hline $\begin{array}{l}\text { Greenish-grey } \\
\text { mudstone }\end{array}$ & $\mathrm{Y}$ & -26.6 & 0.08 & 3 \\
\hline
\end{tabular}

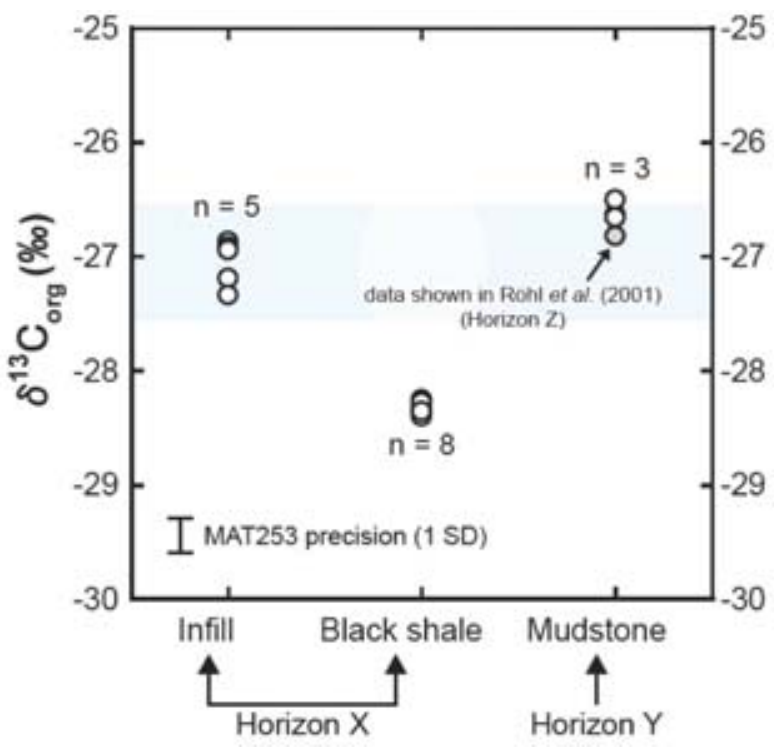

\subsection{Mineralogy}

The bulk-fraction XRD traces obtained for the infill of Chondrites, surrounding black shale, and overlying mudstone are shown in Figures 6 and 7. The constituent minerals are generally the same for three lithofacies; namely quartz, calcite, feldspar, pyrite, and clay minerals are detected (Fig. 6). The obtained results are highly consistent with the previous mineralogical studies in the Posidonia Shale (e.g., Kanitpanyacharoen et al., 2012; Klaver et al., 2012; Ghanizadeh et al., 2014). Peaks of quartz and calcite are the most outstanding, but the peak intensity of feldspar is generally low (Fig. 6). Pyrite peaks for black shale are relatively higher than those for the infill and the overlying mudstone (Fig. 6). Clay minerals are mostly illite and kaolinite for all lithofacies (Fig. 6), but tiny peaks of berthierine can be detected for the infill and black shale (Fig. 7).

\section{DISCUSSION: COMPOSITIONAL VARIATIONS IN THE INFILL OF CHONDRITES FOR ASSESSING THE TRACE-MAKER'S COLONIZATION STYLE}

Because in most cases the infill of Chondrites has been interpreted to have been introduced from the overlying sediment layer (e.g., Richer, 1927, 1931; Simpson, 1957; Ferguson, 1965; Osgood, 1970; Seilacher, 1977a, b), it is highly reasonable that the $\delta^{13} \mathrm{C}_{\text {org }}$ values and mineralogy of the Chondrites infill are much more similar to those of the overlying mudstone, rather than the surrounding black shale (Figs 5, 6). Although there is a slight isotopic difference between the infill and the mudstone $(\sim 0.5 \%)$, there may be several reasons for this, which were also discussed in Izumi (2012): 1) As for the technical reason, the isotope ratio mass spectrometer (ThermoFinnigan MAT 253) has its own precision ( $\pm 0.3 \%$ as 2 SD). 2) Contamination of the infilled sediments in burrows by the ambient black muddy sediments could have happened to some extent. 3) The carbon-isotope values often show

Figure 5. Carbon-isotope values of the Chondrites infill, the surrounding black shale, and the overlying greenishgrey mudstone. Error bar represents the precision of the MAT 253 isotope mass spectrometer. Shade emphasizes the $95 \%$ confidence interval of $\delta^{13} \mathrm{C}_{\text {ors }}$ value of the infill, which is calculated on the basis of an error propagation formula using the precision of the isotope ratio mass spectrometer and sample standard deviation of the obtained isotopic values. 


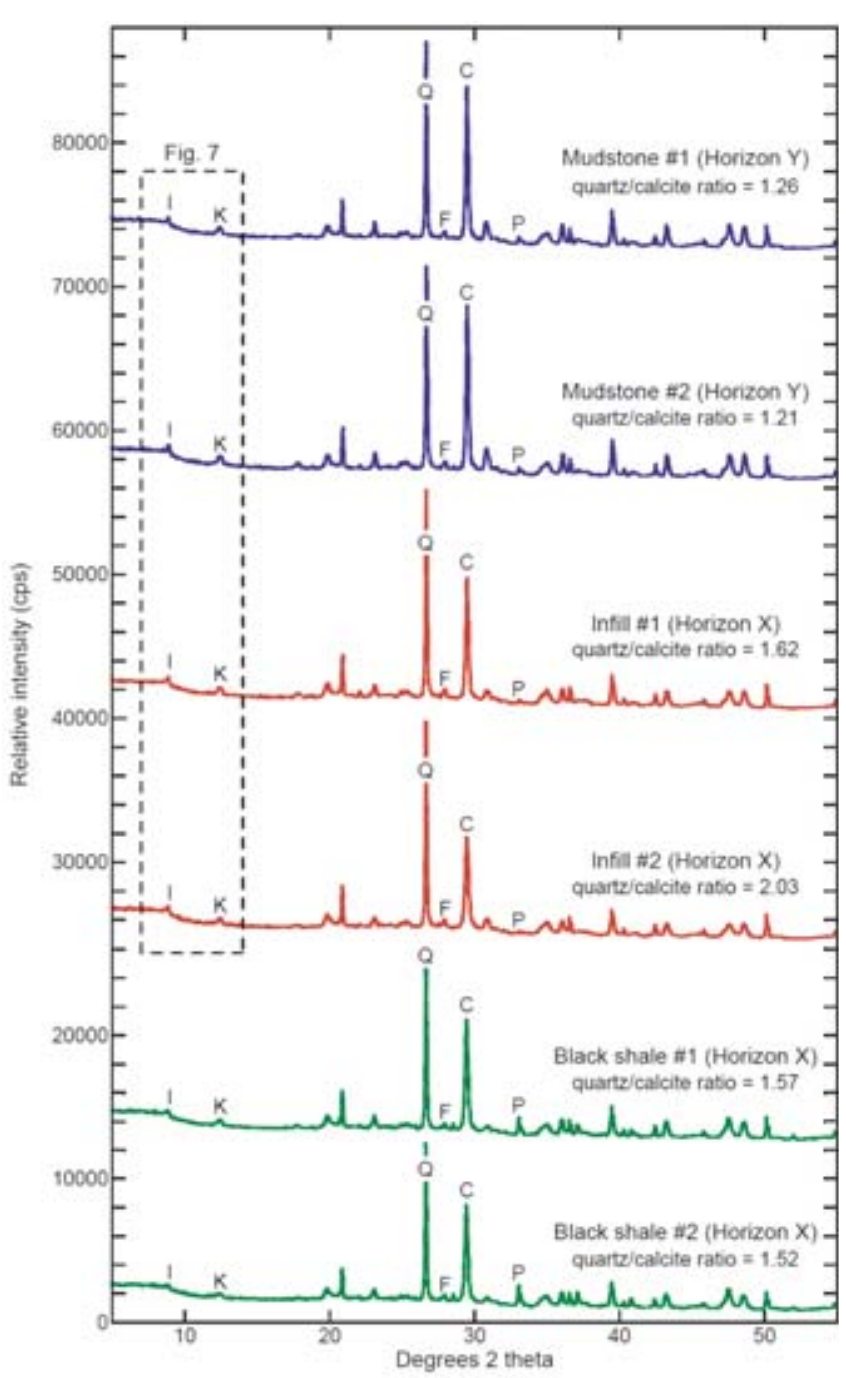

Figure 6. General traces of the bulk-fraction XRD analysis for the infill of Chondrites, the surrounding black shale, and the overlying greenish-grey mudstone. I: illite; K: kaolinite; Q: quartz; F: feldspar; C: calcite; P: pyrite.

inherent variability. Namely, $\delta^{13} \mathrm{C}_{\text {org }}$ measurements for a sequence of marine sediments show fluctuations of up to $0.5 \%$ even between adjacent data points (e.g., Kienast et al., 2001). Furthermore, as for some trace fossils such as Planolites and Thalassinoides from the Cretaceous Agost section of Spain, whose infill was passively filled, the difference of $\delta^{13} \mathrm{C}_{\text {carbonate }}$ value between the infill and overlying sediments can be up to approximately $0.4 \%$ (e.g., Rodríguez-Tovar et al., 2006). Therefore, these carbon-isotope data might provide a reliable ichnological example of the expected variability between source and infilled material. 4) As for an additional reason, it is possible that the mudstone horizon analysed in this study (horizon Y) is not exactly the source-horizon of the infill, although the mudstone was collected from a horizon just above the Chondrites-bearing bed (Fig. 2). In that case, the real origin of the infill must be a different horizon, which might be slightly below or above the horizon Y. The fact that slight peaks of berthierine were recognised only from the infill and the ambient black shale (Fig. 7) may support the possibility of 2 and/or 4 .

In this study, it is highly reasonable to assume that the degree of contamination of the infilled sediments by the surrounding black sediments was constant in all burrows because Chondrites from horizon $\mathrm{X}$ shows more or less similar size and morphology (Fig. 4). Based on this assumption, much more important implications can be obtained only from attention to the isotopic and mineralogical variations recorded in the Chondrites infill. Much larger variation in $\delta^{13} \mathrm{C}_{\text {org }}$ values of the infill (Table 1; Fig. 5), compared with that of the surrounding black shale and overlying mudstone, implies that the infill of Chondrites from the same horizon was introduced from various horizons, clearly suggesting the prolonged upward migration model as proposed by Savrda \& Bottjer (1989) (Fig. 1b). The $\delta^{13} \mathrm{C}_{\text {org }}$ value of horizon $\mathrm{Z}$ (Fig. 2b), which has been already analysed by Röhl et al. (2001), was added in Fig. 5 for comparison and further discussion. According to Röhl et al. (2001), the lithofacies at horizon Z is "light bioturbated marls," and this lithofacies is interpreted to correspond with the greenish-grey homogenized mudstone in this study. Although their $\delta^{13} \mathrm{C}_{\text {org }}$ ratio was obtained from the horizon that is approximately $0.37 \mathrm{~m}$ above horizon $\mathrm{Y}$, this value is highly comparable with heavier $\delta^{13} \mathrm{C}_{\text {org }}$ ratios of the infill obtained in this study (Fig. 5). This fact probably suggests that a portion of the infill of Chondrites from horizon X was substantially derived from quite higher stratigraphical level, which may be not consistent with the short-term opportunistic colonization model proposed by several authors (e.g., Seilacher \& Westphal, 1983; Ekdale, 1985).

Variations in the infill can also be recognised mineralogically. To demonstrate this, XRD peak-heightratios for some minerals were used because these ratios have widely been applied for semiquantitatively evaluating mineralogical differences (e.g., concentration of a specific mineral) between various samples (e.g., Rao \& Gluskoter, 1973; Glaccum \& Prospero, 1980; Ward \& Taylor, 1996). In this study, quartz/calcite ratios were calculated by the peak intensities of these minerals in the general XRD traces (Fig. 6), because peaks of these two minerals are the strongest and therefore may provide relatively reliable data. Peak-height-ratios for clay minerals were also calculated using more accurate XRD traces (Fig. 7), although these values seem to be less reliable than quartz/ calcite ratio because this study carried out not fine-fraction but bulk-fraction XRD analysis. As shown in Fig. 6, quartz/ calcite ratios of the black shale (1.57 and 1.52) and grey mudstone (1.26 and 1.21) seem to have low variations, whereas those of the infill show much larger variation (1.62 and 2.03), although illite/kaolinite ratios of the infill and overlying mudstone both show little variations 


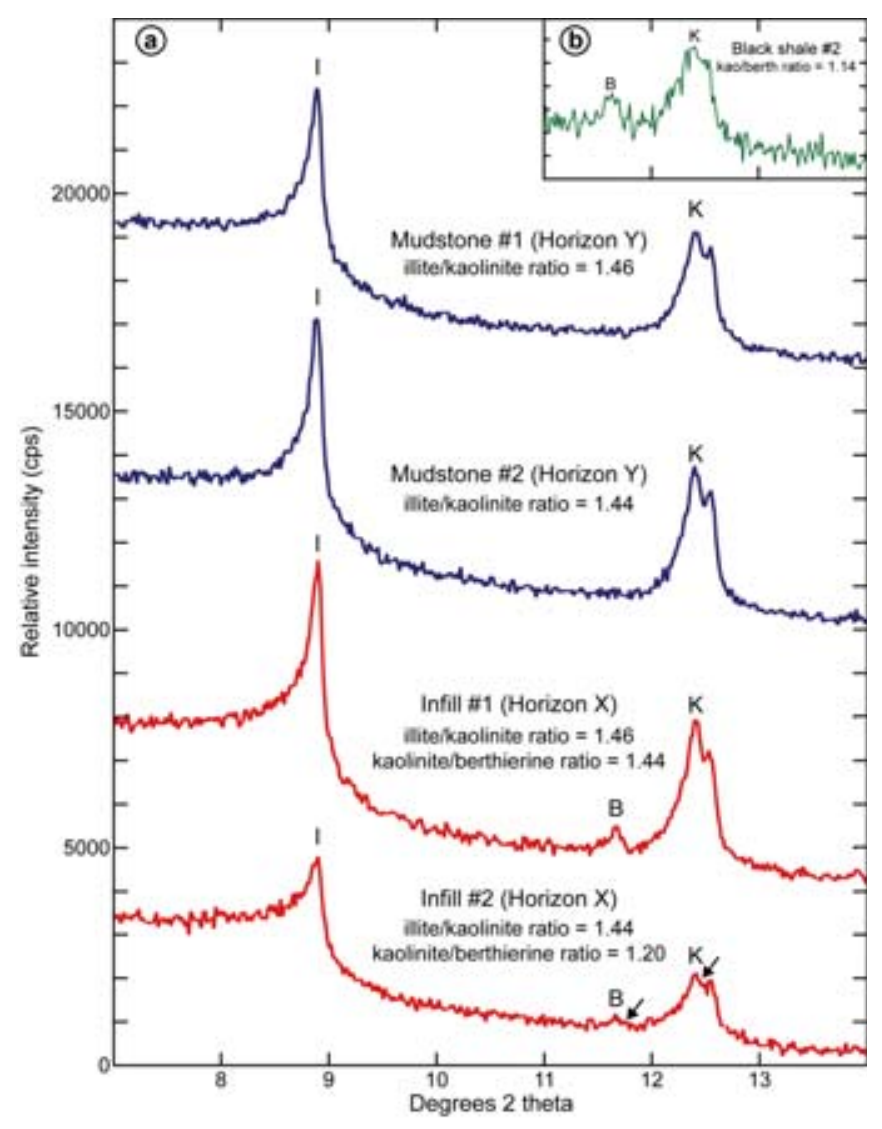

Figure 7. XRD traces emphasizing the low-angle area for the infill of Chondrites and the overlying greenish-grey mudstone (a), and for the black shale as referential data (b). Note a slight increase in the degree of noise in berthierine and kaolinite peaks of Chondrites infill \#2 (black arrows) compared with Chondrites infill \#1. I: illite; B: berthierine; K: kaolinite.

(Fig. 7). Furthermore, kaolinite/berthierine ratios of the infill might have reasonable variation (1.44 and 1.20), but it is somewhat difficult to evaluate the degree of this variation because berthierine was not detected from the grey mudstone (Fig. 7). Due to higher quartz/calcite ratios of the infill than those of the black shale and overlying mudstone, it is not likely that contamination of the infilled sediments in burrows by the ambient black muddy sediments occurred significantly since considerable contamination should have resulted in the intermediate quartz/calcite ratio of the infill. Given all these things, it is highly likely that the infill of Chondrites \#1 and \#2 were introduced from the different horizons, clearly suggesting that the infill of Chondrites from the same horizon (horizon X) was derived from various overlying horizons. A slight increase in the degree of noise in berthierine and kaolinite peaks of Chondrites \#2 (Fig. 7), compared with Chondrites \#1, might also support the difference in original horizons. Thus, the mineralogical data also confirm the prolonged upward migration model (Fig. 1b).
Although the obtained isotopic and mineralogical data cannot directly provide any evidence of the chemosymbiotic producer model, it is now clear that the short-term opportunistic colonization (e.g., Seilacher \& Westphal, 1983; Ekdale, 1985; Fig. 1a) is not likely. This study also suggests that the isotopic and mineralogical variations (not compositional values themselves) recorded in the infill of Chondrites can be used as good indicators for assessing the trace-maker's colonization style. This possibility itself is intriguing; however, there are some issues remaining unsolved or poorly considered. Particularly, mineralogical aspects (e.g., difference in peak-height-ratios) cannot be statistically considered due to the lack of the obtained data and fine-fraction analysis. Therefore, to verify the utility of compositional variations for evaluating the mode of colonization, a number of case studies on other Chondrites specimens and further mineralogical/geochemical studies are both needed.

\section{CONCLUSIONS}

The compositional variations of the infill of the trace fossil Chondrites from the Toarcian black shale of southern Germany were evaluated on the basis of carbon-isotope and mineralogical analyses of the infill, ambient black shale, and overlying greenish-grey mudstone in order to assess the colonization style by the trace-maker. Both $\delta^{13} \mathrm{C}_{\text {org }}$ value and the mineralogical composition (i.e., quartz/calcite peak-height-ratio) of the infill have much larger variations than those of the overlying mudstone and surrounding black shale. These lines of evidence clearly confirm the prolonged upward migration model, and the short-term opportunistic colonization model is not likely in this case. Though the obtained data cannot directly provide any evidence of the chemosymbiotic trace-maker model, this paper suggests that the isotopic and mineralogical variations recorded in the infill of Chondrites can be used as good indicators for assessing the mode of colonization, furthermore for distinguishing opportunistic or climax form. To further verify the utility, more detailed case studies are required.

\section{ACKNOWLEDGEMENTS}

This work is dedicated to Jordi Maria de Gibert Atienza, and I pray from the bottom of my heart that his soul may rest in peace. I would like to thank Kazushige Tanabe (The University Museum, University of Tokyo) for his supervision throughout this study. I greatly appreciate the kind assistance of Manfred Jäger (Werkforum und 
Fossilienmuseum, Dotternhausen) with my fieldwork in the Dotternhausen section and for helpful discussion in the field. I am also indebted to Kotaro Shirai (University of Tokyo) for his help in the field in the Dotternhausen section; Megumi Saito-Kato (National Museum of Nature and Science, Tokyo) and Tsuzumi Miyaji (Hokkaido University) for their assistance with carbon-isotope analysis; Akihiro Kobayashi (University of Tokyo) for his assistance with XRD analysis. This work was financially supported by the Sasakawa Scientific Research Grant from The Japan Science Society awarded to KI (23-612). Thanks are also due to Alfred Uchman (Uniwersytet Jagielloński) and Guo Qingjun (Chinese Academy of Sciences), who improved the manuscript substantially.

\section{REFERENCES}

Bassoulet, J.P., Elmi, S., Poisson, A., Cecca, F., Bellion, Y., Guiraud, R. \& Baudin, F. 1993. Mid Toarcian. In: Atlas of Tethys Paleoenvironmental Maps (eds Dercourt, J., Ricou, L.E. \& Vrielynck, B.). Beicip-Franlab, Rueil-Malmaison, France, 63-80.

Bromley, R.G. 1996. Trace Fossils: Biology, Taphonomy and Applications. Chapman \& Hall, London.

Bromley, R.G. \& Ekdale, A.A. 1984. Chondrites: A trace fossil indicator of anoxia in sediments. Science, 224, 872-874.

Buatois, L.A. \& Mángano, M.G. 2011. Ichnology: OrganismSubstrate Interactions in Space and Time. Cambridge University Press, Cambridge.

Ekdale, A.A. 1985. Paleoecology of the marine endobenthos. Palaeogeography, Palaeoclimatology, Palaeoecology, 50, 63-81.

Ekdale, A.A. \& Mason, T.R. 1988. Characteristic trace-fossil associations in oxygen-poor sedimentary environments. Geology, 16, 720-723.

Ferguson, L. 1965. A note on the emplacement of sediment in the trace fossil Chondrites. Proceedings of the Geological Society of London, 1622, 79-82.

Frimmel, A., Oschmann, W. \& Schwark, L. 2004. Chemostratigraphy of the Posidonia black shale, SW Germany I. Influence of sea-level variation on organic facies evolution. Chemical Geology, 206, 199-230.

$\mathrm{Fu}, \mathrm{S} .1991$. Funktion, Verhalten und Einteilung fucoider und lophocteniider Lebensspuren. Courier Forschung-Institut Senckenberg, 135, 1-79.

Fu, S. \& Werner, F. 1994. Distribution and composition of biogenic structures on the Iceland-Faeroe ridge: Relation to different environments. Palaios, 9, 92-101.

Gerard, J. \& Bromley, R.G. 2008. Ichnofabrics in Clastic Sediments. Applications to Sedimentological Core Studies. A Practical Guide. J. Gerard, Madrid.

Ghanizadeh, A., Amann-Hildenbrand, A., Gasparik, M., Gensterblum, Y., Krooss, B.M. \& Littke, R. 2014.
Experimental study of fluid transport processes in the matrix system of the European organic-rich shales: II. Posidonia Shale (Lower Toarcian, northern Germany). International Journal of Coal Geology, 123, 20-33.

Glaccum, R.A. \& Prospero, J.M. 1980. Saharan aerosols over the tropical north Atlantic-Mineralogy. Marine Geology, 37, 295-321.

Izumi, K. 2012. Formation process of the trace fossil Phymatoderma granulata in the Lower Jurassic black shale (Posidonia Shale, southern Germany) and its paleoecological implications. Palaeogeography, Palaeoclimatology, Palaeoecology, 353-355, 116-122.

Izumi, K. 2013. Geochemical composition of faecal pellets as an indicator of deposit-feeding strategies in the trace fossil Phymatoderma. Lethaia, 46, 496-507.

Kanitpanyacharoen, W., Kets, F.B., Wenk, H.-R. \& Wirth, R. 2012. Mineral preferred orientation and microstructure in the Posidonia Shale in relation to different degrees of thermal maturity. Clays and Clay minerals, 60, 315-329.

Kauffman, E.G. 1981. Ecological reappraisal of the German Posidonienschiefer (Toarcian) and the stagnant basin model. In: Communities of the Past (eds Gray, J., Boucot, A.J. \& Berry, W.B.N.). Hutchinson Ross, Stroundsburg, 311-381.

Kienast, M., Calvert, S.E., Pelejero, C. \& Grimalt, J.O. 2001. A critical review of marine sedimentary $\delta^{13} \mathrm{C}_{\text {org }}-\mathrm{pCO}_{2}$ estimates: New palaeorecords from the South China Sea and a revisit of other low-latitude $\delta^{13} \mathrm{C}_{\mathrm{org}}-\mathrm{pCO}_{2}$ records. Global Biogeochemical Cycles, 15, 113-127.

Klaver, J., Desbois, G., Urai, J. \& Littke, R. 2012. BIBSEM study of the pore space morphology in early mature Posidonia Shale from the Hils area, Germany. International Journal of Coal Geology, 103, 12-25.

Knaust, D. \& Bromley, R.G. 2012. Trace Fossils as Indicators of Sedimentary Environments. Developments in Sedimentology, 64. Elsevier, Amsterdam.

Kotake, N. 1991. Packing process for the filling material in Chondrites. Ichnos, 1, 277-285.

Krasser, X. 1889. Über den Kohlengehalt der Flyschalgen. Annalen des Naturhistorischen Hofmuseums, 4, 183-187.

Mángano, M.G. \& Buatois, L.A. 2012. A multifaceted approach to ichnology. Ichnos, 19, 121-126.

Osgood, R.G. 1970. Trace fossils of the Cincinnati area. Palaeontolographica Americana, 6, 281-444.

Pfaft, F.W. 1901. Bemerkung über Chondriten und ihre Entstehung. Geognostische Jahreshefte, 14, 129-138.

Rao, C.P. \& Gluskoter, H.J. 1973. Occurrence and distribution of minerals in Illinois coals. Illinois State Geological Survey, Circular 476, 1-56.

Richter, R. 1927. Die fossilen Fährten und Bauten der Würmer, ein Überblick überrihre biologischen Grundformen und deren beologische Bedeutung. Paläontologische Zeitschrift, 9, 193-235.

Richter, R. 1931. Tierwelt und Umwelt in Hunsrückschiefer; zur Entstehung eiens schwarzen Schammsteins. Senckenbergiana, 13, 299-342.

Riegraf, W., Werner, G. \& Lörcher, F. 1984. Der Posidonienschiefer: Biostratigraphie Fauna und Fazies 
des südwestdeutschen Untertoarciums (Lias Epsilon). Enke, Stuttgart.

Rodríguez-Tovar, F.J., Martínez-Ruiz, F. \& Bernasconi, S.M. 2006. Use of high-resolution ichnological and stable isotope data for assessing completeness of a K-P boundary section, Agost, Spain. Palaeogeography, Palaeoclimatology, Palaeoecology, 237, 137-146.

Röhl, H.-J. \& Schmid-Röhl, A. 2005. Lower Toarcian (Upper Liassic) black shales of the central European epicontinental basin: A sequence stratigraphic case study from the SW German Posidonia Shale. In: The Deposition of Organic-Carbon-Rich Sediments: Models, Mechanisms, and Consequences (ed. Harries, N.B.). Society for Sedimentary Geology Special Publication, 82, 165-189.

Röhl, H.-J., Schmid-Röhl, A., Oschmann, W., Frimmel, A. \& Schwark, L. 2001. The Posidonia Shale (Lower Toarcian) of SW-Germany: An oxygen-depleted ecosystem controlled by sea level and palaeoclimate. Palaeogeography, Palaeoclimatology, Palaeoecology, 165, 27-52.

Savrda, C.E. \& Bottjer, D.B. 1986. Trace-fossil model for reconstruction of palaeo-oxygenation in bottom waters. Geology, 14, 3-6.

Savrda, C.E. \& Bottjer, D.J., 1989. Anatomy and implications of bioturbated beds in "black shale" sequences: Examples from the Jurassic Posidonienschiefer (southern Germany). Palaios, 4, 330-342.

Schmid-Röhl, A. \& Röhl, H.-J. 2003. Overgrowth on ammonite conchs: Environmental implications for the lower Toarcian Posidonia Shale. Palaeontology, 46, 339-352.

Schwark, L. \& Frimmel, A. 2004. Chemostratigraphy of the Posidonia black shale, SW-Germany II. Assessment of extent and persistence of photic-zone anoxia using aryl isoprenoid distributions. Chemical Geology, 206, 231-248.

Seilacher, A. 1967a. Fossil behaviour. Scientific American, 217, $72-80$.
Seilacher, A. 1967b. Bathymetry of trace fossils. Marine Geology, 5, 413-428.

Seilacher, A. 1977a. Pattern analysis of Paleodictyon and related trace fossils. In: Trace Fossils 2 (eds Crimes, T.P. \& Haper, J.C.). Geological Journal, Special Issue, 9, 289-334.

Seilacher, A. 1977b. Evolution of trace fossil communities. In: Pattern of Evolution, as Illustrated by the Fossil Record (ed. Hallam, A.). Elsevier, Amsterdam, 359-376.

Seilacher, A. 1990. Aberrations in bivalve evolution related to photo- and chemosymbiosis. Historical Biology, 3, 289-311.

Seilacher, A. 2007. Trace Fossil Analysis. Springer-Verlag, Berlin.

Seilacher, A. \& Westphal, F. 1983. Remarkable fossiliferous localities in southern Germany. Field Trip Guidebook 12B, First International Congress on Paleoecology, Lyon, France, $26 \mathrm{p}$.

Simpson, S. 1957. On the trace fossil Chondrites. Quarterly Journal of the Geological Society of London, 112, 475499.

Tauber, A.F. 1949. Paläobiologische analyse von Chondrites furcatus Sternberg. Jahrbuch der Geologische Bundesanstalt Wien, 92, 141-154.

Ward, C.R. \& Taylor, J.C. 1996. Quantitative mineralogical analysis of coals from the Callide Basin, Queensland, Australia using X-ray diffractometry and normative interpretation. International Journal of Coal Geology, 30, 211-229.

Ziegler, P.A. 1982. Geological Atlas of Central and Western Europe. Shell International Petroleum Maatschappij B.V., Amsterdam.

Ziegler, P.A. 1988. Evolution of the Arctic-North Atlantic and the Western Tethys. American Association of Petroleum Geologists, Memoirs, 43. 